Chinese Journal of Oceanology and Limnology

Vol. 29 No. 1, P. 232, 2011

DOI: 10.1007/s00343-011-0232-2

\title{
ERRATUM
}

\section{Erratum to: Using genetic algorithms to calibrate a dimethylsulfide production model in the Arctic Ocean}

QU Bo (瞿波), GABRIC J. Albert

(C) Chinese Society for Oceanology and Limnology, Science Press and Springer-Verlag Berlin Heidelberg 2011

Erratum to: Chinese Journal of Oceanology and Limnology

Vol. 28 No. 3, P. 573-582, 2010

DOI: 10.1007/s00343-010-9062-x

In the original article, the name of the second author (GABRIC J. Albert) should be Albert J. GABRIC, in which "GABRIC" is the family name.

The online version of the original article can be found at http://dx.doi.org/10.1007/s00343-010-9062-x 